\title{
Students' Perspective towards Arabic Class Based on Gender
}

\author{
Nuril Mufidah ${ }^{1 *}$, Filza Aina Hanini ${ }^{2}$ \\ ${ }^{1}$ Pendidikan Bahasa Arab Universitas Islam Negeri Maulana Malik Ibrahim Malang, Indonesia \\ ${ }^{2}$ Pendidikan Bahasa Arab Universitas Islam Negeri Maulana Malik Ibrahim Malang, Indonesia
}

\section{Article History:}

Received : March $6^{\text {th }}, 2019$

Revised : April $8^{\text {th }}, 2019$

Accepted : May $10^{\text {th }}, 2019$

Published : June $1^{\text {st }}, 2019$

Keywords:

Arabic; Gender; Grouping;

Perspective

*Correspondence Address:

nurilmufidah86@uin-malang.ac.id

\begin{abstract}
The grouping system of students in learning can effect on the learning process. This research used a descriptive qualitative method to describe the perspective of students of the Arabic Language Development Program (PKPBA) on the classifying system based on gender, which is divided into homogeneous classes (separate classes between students and college students) and heterogeneous classes (mixed classes of students). Data collection used observation of teaching and learning activities and interviews. The results of the study show a different perspective between men and women. Female students are more comfortable learning in homogeneous classes, especially beginner classes' so they are not ashamed to learn and practice Arabic even though their abilities are minimal. In contrast to the perspective of male students who are more comfortable in heterogeneous classes, they feel they can learn better. Learning feels vibrant and increases academic competitiveness because they are challenged to perform well in front of female students, including when practicing Arabic. To make students learn better and the ability to speak Arabic tends to increase.
\end{abstract}

\section{Introduction}

Arabic is the key to understanding and studying Islam. Especially for students who are studying the sciences of Islam in Islamic Higher Education, having good Arabic language skills is something that is needed. That is why State Islamic University of Maulana Malik Ibrahim Malang requires learning Arabic in a full year for all new students in all majors. In addition, the integration of Islam and science requires students from other faculties such as faculties of science and technology to fluently read and write the Qur'an and be able to speak Arabic.

In learning Arabic, it indirectly will make students recognize the letters of the Qur'an and be able to write them. More than that, the ability to speak Arabic will be an additional value for alumni in their career and international. It will have a positive impact on students in the future. 
Muslim scholars must know the original references from the main book / book which in the study of Islamic sciences are written in Arabic. Indirectly, it can be said that to learn the Arabic literatures, they certainly must understand Arabic as well. Meanwhile, not all the students who get into Islamic universities have studied or known Arabic. They will be difficult in understanding Arabic literatures while they do not understand Arabic. It is such a problem that needs to be addressed and solved. One effective way that can be done is by holding a special program for Arabic learning in an Islamic university.

State Islamic University of Maulana Malik Ibrahim Malang is one of the Islamic Universities in which there is an intensive Arabic language development program, namely, the Arabic Language Development Program (PKPBA) which is specified and as a obligation for every student in State Islamic University of Maulana Malik Ibrahim Malang who is on first and second semester. This program is compulsory for all departments at State Islamic University of Maulana Malik Ibrahim Malang. Arabic Language Development Program (PKPBA) was held with the aim of equipping students with the ability to read and understand Arabic texts, and translate Arabic books, with mission of making Arabic a language of communication in State Islamic University of Maulana Malik Ibrahim Malang, and as a tool to understand Al-Qur'an text, As-Sunnah and Islamic books. (Program Khusus Pengembangan Bahasa Arab, 2017, p.4).

Teaching and learning activities in Arabic Language Development Program (PKPBA) pay attention to and prioritize the development of basic skills in Arabic, namely listening skills (Maharah Al-Istima '), speaking skills (Maharah Al-Kalam), reading skills (Maharah Al-Qiraah), and writing skills (Maharah Al-Kitabah) (Program Khusus Pengembangan Bahasa Arab, 2017, p.19).

Arabic Language Development Program (PKPBA) teaching activities are conducted based on classes according to the ability of students. Students of all majors certainly have different abilities regarding learning Arabic. Moreover, their notions come from different educational institutions so that not all students have ever studied Arabic before. Then Arabic learning activities in Arabic Language Development Program (PKPBA) cannot be generalized for each class. Class distribution is based on the results of the placement test. This test is to determine the grouping of students based on cognitive students in Arabic language skills. The division of class levels is divided into three, namely the beginner level (mubtadi'), middle level (mutawasssith) and upper level (mutaqoddim). 
In recent years there have been several system changes in the grouping of students in Arabic Language Development Program (PKPBA) in State Islamic University of Maulana Malik Ibrahim Malang. These changes are not only based on knowledge aspects, but are based on gender aspects.

In the grouping system of students, data can be obtained in the 2016/2017 school year this system based on homogeneous classes, i.e. in one class only consisted of male students or female students from various majors at State Islamic University of Maulana Malik Ibrahim Malang. In the 2017/2018 school year, the grouping system of students used a homogeneous system, but one group was from the same faculty. Until the 2018/2019 school year, heterogeneous class was implemented, and in one class, the students came from the same faculty.

The change in some systems in grouping these students certainly has various impacts on classroom learning activities. The purpose of this study is to describe students' perceptions of the grouping system of students by gender. In addition, it also analyzes the advantages and disadvantages of the system of grouping homogeneous and heterogeneous students in Arabic Language Development Program (PKPBA) in State Islamic University of Maulana Malik Ibrahim Malang. The results of this study are useful for the organizers of education and teaching Arabic in class organizing or grouping the students.

\section{Theoritical Support}

\section{Grouping System of Students}

Grouping students is a school's way to provide maximum service to students. According to Imron (Zakia, 2011, p.202), a student placement is as the characteristics that exist in students and can be called as grouping. It aims the teachers can more easily give attention or service to students. Grouping students is also often called classification.

Students' grouping varies, from the simple to the complex one, it is according to the purpose of the grouping. As the conclusions which presented by the AP Lecturer Team (Zakia, 2011, p.203), that "The grouping of students is intended that the implementation of learning in schools can run well, so as to achieve the objectives of the education program".

According to the Education Administration Lecturer Team University of Indonesia (Taqiyah, 2016, p.11) William A. Jeager classifies students based on the functions: (a). 
Integration function is a grouping based on the similarities that exist in students. As based on gender, general and others. This grouping results in classical learning. Whereas (b). Difference Function is a grouping of students based on individual differences, because it produces individual learning, such as talents, interests, abilities and others.

As for the other types of grouping according to Regan (in Zakia, 2011, p.202) there are seven types of grouping of students, namely: 1). The noun grade elementary school is a grouping of students in elementary schools without any class level; 2). Multi grade and multi age grouping is a primary school with a level system; 3). Multiple progress plan is the grouping to overcome differences in abilities among students; 4). Placement of a group of students by a teacher (self combined classroom) is a grouping as well as a classroom teacher; 5). Team teaching is grouping of students who are given learning by teachers in the form of teams; 6). Departmentalization is grouping students with teachers only specializing in one subject area; and 7). Ability grouping is a grouping system of students by adjusting the abilities of students.

\section{Grouping of Students Based on Gender}

Gender is a difference in biological nature between of both gender and resulting in psychological behaviour differently. Or as a distinction between women and men based on the culture of society, social construction, also the biological conditions of human being, then this is what is called as gender. In social science, gender is defined as a pattern of relations between men and women. Like the division of labor, patterns of reaction of power, equipment, behavior to perspectives that distinguish others. (Rayhan Putri, 2016, p.168)

In the realm of Indonesian education, gender is also considered in its implementation. In education, the existence of gender equality as a freedom which requires equality between men and women (Warni Tune Sumar, 2004, p. 170)

According to Damsar in (Iqbal, 2018, p.27) the management system of students in learning, there is a grouping of students in a mixture. It is a learning with heterogeneous classes in which there are two genders, men and women who are in the same room. However, there is also a homogeneous class grouping system in a learning class that is occupied by students from similar gender backgrounds. Or it can be said that the class is divided between men and women, in one class there is only one gender, it isthe female class only or the male class only. 
According to Megasari et al., The research stated that the existence of class separation had a good impact on social interaction. Students are more focused and enthusiastic in paying attention to learning from the teacher, can be seen from the presence of students who respond to learning by teaching questions to the teacher (Megasari et al, 2014, p.5)

The class separation between male and female students is a system of students grouping which based on different gender with other classes. Class grouping based on gender aims to enable male and female students to lead their own class (Imam Ahmadi, 2015, p.1) The class separation between male and female students also to avoid the social problems that deviate from the goal education (Assegaf, 2013, p.73). According to (Glimore, 2002), class separation can build students' motivation in learning, so as to make learning conditions more focused, and can improve their self-confidence. The conditions in the men's class, the majority of the students often banter and open to each other in learning.

According to Khodijah (Saraswati, 2015, p.23) based on gender, the characteristics of men and women are different. In general, female students will be more diligent than male students. As stated by Sadker in (Yulianto \& Dwijananti, 2013, p.27) about the relationship between learning outcomes with gender. The conditions in the girls' special class interact well because of their communication skills with their classmates, so they become close to each other in the class.

The learning environment in a special class of women can be avoided from psychological stress, ambitions, and social interactions from men who always want to control. With special women classes, students can develop and improve their ability in the learning process. (Muhammad Rasyid Al-Uwaid, 2005, p.282). In the separate class, women are free to express themselves and behave in all activities and are able to show strong feminist characteristics (Inne Marta Fauziyah, 1997).

In mixed classes, the form of cooperation is better than in a special female class, because they are easy to adapt to each other. The individual factors of each student will also influence. In female students group work, they are more active than male students. But, there are also negative impacts that occur in the mixed class as in Gilmore's research (Yulianto \& Dwijananti, 2013, p.29). The presence of male students will have an effect on emotions and behavior in female students who will feel loss. Sometimes there is 
awkwardness among male and female students, so they feel embarrassed to communicate with each other. When in a separate class women are free to express themselves and behave in all activities and are able to show strong feminist characteristics (Inne Marta Fauziyah, 1997).

In a mixed class, the existence of the opposite gender causes a negative impact on students' emotions and behavior. Otherwise, some students are excited because of the opposite gender in one class. In the discovery of Reni and Parker, the results of research in mixed classes obtained that there was a positive competition in the academic field among students, which was controlling the negative things of male students. (Yulianto \& Dwijananti, 2013, p.31).

According to Yulianto, Reni and Parker, there is a positive influence from the opposite gender in the mixed class, the learning process has a better results. However, according to Rennie and Parker in mixed-class research, women are controlling male students from aspects of behavior (Rennie, L, J \& Parker, 1997, p.257)

Another study about the schools in the UK found that female students who study at girls' school are smarter than female students in mixed school. It was also found that 71,286 students who took part in the girls' secondary school program between 2005 and 2007 had a better results. Meanwhile, more than 647,942 female students who took the mixed school examinations obtained $20 \%$ not as expected..

\section{Arabic Language Development Program at State Islamic University of Maulana Malik Ibrahim Malang.}

The Arabic Language Development Program (PKPBA) State Islamic University of Maulana Malik Ibrahim Malang is an institution that is given the responsibility to handle Arabic language lectures which are managed with a special program. (Program Khusus Pengembangan Bahasa Arab, 2017, p.5). This special Arabic language learning program must be followed by all students in the first and second semester for one year of learning from all faculties and departments intensively. The academic department has arranged a learning schedule for each semester. The teaching and learning process can be done in 
the classroom or in green campus parks, by sitting on the floor or grass, and using active methods. (Program Khusus Pengembangan Bahasa Arab, 2017, p.17).

The Arabic Language Development Program (PKPBA) of State Islamic University of Maulana Malik Ibrahim Malang stands with the mission of Making Arabic the language of communication for all the students of State Islamic University of Maulana Malik Ibrahim Malang as well as a tool to understand the text of Al-Quran, the Sunnah and Islamic books (Program Khusus Pengembangan Bahasa Arab, 2017, p.3). The vision is realized with its mission. Delivering all students from all departments to have the ability and skills in Arabic as a whole and to develop models of learning Arabic in a creative, joyful and encouraging way. (Program Khusus Pengembangan Bahasa Arab, 2017, p.4)

Whereas the purpose of Arabic Language Development Program (PKPBA) State Islamic University of Maulana Malik Ibrahim Malang in the implementation of learning has the goal as follows ; 1). Equipping students the ability to communicate in Arabic spoken amd written; 2) Equipping students the ability to read and understand Arabic texts and translate Arabic books; 3) The creation of Bi'ah Arabiyah in the campus environment; and the final goal is 4) Strengthening the synergy with the departments and faculties to generate the prospective Islamic scholars who have the ability to study Arabic-language literature independently, so that the hope of them being able to develop Islamic sciences further can be realized. So with a vision and mission together with its objectives, Arabic Language Development Program (PKPBA) is able to be undergone and realized until now. (Program Khusus Pengembangan Bahasa Arab, 2017, p.4).

The implementation of Arabic learning at Arabic Language Development Program (PKPBA) in State Islamic University of Maulana Malik Ibrahim Malang has schedule on Monday to Friday from 14.00-17.00 WIB, and it is divided into 2 meetings a day, where each meeting lasts for 90 minutes. The aspects taught in Arabic Language Development Program (PKPBA) are Arabic skills, namely Maharoh Istima ', Maharoh Kalam, Maharoh Qiro'ah and Maharoh Kitabah. These aspects of learning are taught by using methods, teaching materials and learning media that are suitable with the ability level of students. 


\section{Method}

This research was conducted at Arabic Language Development Program (PKPBA) in State Islamic University of Maulana Malik Ibrahim Malang. This research is descriptive qualitative research. This study aims to describe students' perceptions of the Grouping system of students by gender and analyzing the advantages and disadvantages of the grouping system of students in Arabic Language Development Program (PKPBA) in State Islamic University of Maulana Malik Ibrahim Malang.

The subjects of this study were conducted with some Arabic Language Development Program (PKPBA) students of State Islamic University of Maulana Malik Ibrahim Malang in the academic year of 2017/2018 as the informants of the utilization of grouping system for students homogeneously and Arabic Language Development Program (PKPBA) and students from State Islamic University of Maulana Malik Ibrahim Malang in the academic year of 2018/2019 as informants of the utilization of grouping system for students heterogeneously.

The method of data collection in this study used observation instruments, and interviews (Arifin, 2016, p.153). Observations were made to obtain class group information and student reactions during the teaching and learning process. Interviews were conducted to students that study in Arabic Language Development Program (PKPBA) in State Islamic University of Maulana Malik Ibrahim Malang in the academic year of 2017/2018 and 2018/2019 to find out their perceptions of the grouping system of students in Arabic Language Development Program (PKPBA) in State Islamic University of Maulana Malik Ibrahim Malang and the impacts that they felt in the class. Data analysis used triangulation data.

The stages which carried out in the research towards grouping system of students includes: The observation stage, conducting observations during the learning activities. Then interviewing stage, conducting interviews with 5 students and 5 students in Arabic Language Development Program (PKPBA) in State Islamic University of Maulana Malik Ibrahim Malang which studied in mubtadi 'class, mutawassith and mutaqoddim academic year of 2017/2018 and 2018/2019 with 60 informants. 


\section{Result and Discussion}

1. Grouping of Students in Arabic Language Development Program (PKPBA) in State Islamic University of Maulana Malik Ibrahim Malang.

The learning process of the Special Arabic Language Learning Program was carried out in the class in State Islamic University of Maulana Malik Ibrahim Malang, precisely in buildings A, B, and C. Arabic Language Development Program (PKPBA) was under the responsibility of the Language Development Center of State Islamic University of Maulana Malik Ibrahim Malang, precisely in building C (Arabic Language Development Program, 2017, p.7). The media and learning facilities which is used in Arabic Language Development Program (PKPBA) learning include Satellite Dish, (al-qamar al-shina'iy), Arabic videos, Arabic language laboratories, computer and multimedia laboratories, and open classes. (Program Khusus Pengembangan Bahasa Arab, 2017, p.27)

The grouping system of students applied in Arabic Language Development Program (PKPBA) in State Islamic University of Maulana Malik Ibrahim Malang based on the level of students' ability that obtained from the results of the placement-test in the form of a written test (Ibid. p.15). The form of the written test consists of 45 multiple choice questions and 5 description questions. The aspects that are tested in the written test included word identification, discourse text analysis, understanding vocabulary, taroqib and qowaid, and writing Arabic ${ }^{1}$.

The division of class levels is divided into three, namely the beginner level (mubtadi '), middle level (mutawasssith) and upper level (mutaqoddim). After obtaining the results of the placement-test based on the level of ability, there is more classification based on gender, namely homogeneous and heterogeneous class. As Damsar argues in Adib Faisol Iqbal which states that learning with heterogeneous classes in which there are 2 types of gender, men and women, who are in the same room while in a system of grouping homogeneous classes, in the class there is only one gender, women or men (Adib Faisol Iqbal, 2018, p.27).

The grouping of students which based on gender has been several system changes in the past few years. In the academic year of 2017/2018, a system of homogeneous grouping of students was applied, and in the academic year of 2018/2019, a system heterogeneous grouping of students was applied. Hence, the researcher conducted the

\footnotetext{
${ }^{1}$ Interview with Ustad Ibnu Ahmad (academic staff of PKPBA UIN Malang), Friday, December 06. 2018.
} 
research to the grouping system of the students. How if the learning conditions in class when in one class are all female students, or male students, or mixed. Then different impacts will arise. The following details are a description of the problem formulation in this study.

\section{The Students' Perspective towards Class Grouping}

From the results of research data on Arabic Language Development Program (PKPBA) in 2017, students who applied a homogeneous class grouping system whose classes were divided between female students and male students for all levels, whether the mubtadi 'level, mutawassith until mutaqoddim, showing a diverse student perspective. The diverse perspectives were based on differences of opinion of each individual both the opinions of students, the opinions of students and their level of class.

Most students at the mutaqoddim level did not agree about homogeneous class grouping system, according to them, if in one class only contained one gender, learning process in the classroom would be boring and monotonous. It made them lack of enthusiasm and feel lazy to learn in the classroom. Even in learning process, there is a lack of academic competition because they were grouped with the same gender. But there were times when they felt free to express themselves and feel confident. But, when the students felt too confident, the students usually slept in class.

But there were also students who agree, because the implementation of a homogeneous class grouping system made students easy to interact in one class. Moreover, with one class that has only one gender in it, it would also minimize relations between the opposite gender. Likewise, the results of research on mutawassith level students, most students had the same perspective as mutaqoddim level students. When they were in a homogeneous class, they felt that classroom learning was monotonous and tedious, even the class conditions were difficult to be controled because many students did not pay attention and they were noisy. Especially if the teaching lecturer was absent, they were unified to immediately leave the class.

By learning using a homogeneous grouping system, students can explore their Arabic without feeling embarrassed. With this, students are more active in learning. This also occurs in the homogeneous level of the mubtadi class which has a lack of Arabic language skills compared to the other two classes, namely mutaqoddim and mutawassith. Most of them are more active in class because of the absence of the opposite gender, 
because they are still in the learning phase of beginners in learning Arabic, which learn Arabic is something new to them. However, some students in the Mubtadi class also felt lack of enthusiasm in the learning process with a homogeneous class grouping system, as perceived by students who sat in the Mutawassith and Mutaqoddim classes.

Then from the student perspective on the system of grouping homogeneous students applied in the PKPBA in 2017 at the mubtadi ', mutawassith and mutaqoddim levels. Most of their perspectives were the same, namely they were more comfortable being in a homogeneous class than having to be mixed with students in one class. They could be more active and easy to express because they were shy to the opposite gender. Then, Arabic learning activities became more effective and conducive. In addition, they found it easier to concentrate on learning in a homogeneous class, especially female students in the Mutaqoddim class, who had been in advanced level, so the learning Arabic ran well.

Students in the Mutawassith class who had the basic ability to speak Arabic, they could develop basic Arabic in a homogeneous class. Because they were more confident when in a class separate from the opposite gender. But there were some students who had different perspectives, namely they felt less motivated by learning in separate classes. It also happened to the mubtadi class students' perspective, they were beginner Arabic language learners. Most of them thought that feeling could be more comfortable, but it made students behave as what they like, such as sleeping in the class, being lazy or even made noise in the classroom.

Students who were categorized as low-ability from other levels, in learning Arabic, they had their own perspectives for benig enthusiasm in learning, some students would be more enthusiastic and focused on learning systems separately and some other students felt less enthusiasm in learning Arabic apart, because they felt they would be more enthusiastic when they are in the class where there are interactions between female students and male students in it. They also felt when in a class that is homogeneuous, they were easier to interact to each other.

It is different from the results of the research data on PKPBA in 2018 when heterogeneous class grouping system was applied, one class consisting of male students and female students from all levels, the mubtadi 'level, mutawassith to mutaqoddim showing a diverse student perspective. The diverse perspective was based on differences 
of opinion of each individual both the opinions of students, the opinions of students and their level of class.

The majority perspective of students in the Mutaqoddim class was agreeing with the application of heterogeneous systems in Arabic learning classes, they could interact with the opposite gender in learning and could build their academic competitiveness. It made their enthusiastic in learning Arabic in the classroom increased. But there are some students who felt shy of the opposite gender when in the class. They could share insights and experiences about Arabic in heterogenous class.

Students in the Mutawassith class had the same perspective as students in the Mutaqoddim class. They were more enthusiastic in participating in learning when they were in heterogeneous classes. But it had led to ineffective learning because many students and students were not focused to study in the class. Students in mubtadi class agreed with learning in heterogeneous classes. In their opinion, they could do brainstorm and share experiences about learning Arabic. Similar to students in the Mutaqoddim and Mutawassith classes, they felt more enthusiastic in learning when they were in mixed classes, they felt more fun and comfortable in the classroom. But several of the students are less focused when studying.

Then, the students' perspective about the grouping system of homogeneous students which was applied on PKPBA in 2018, at the mubtadi', mutawassith and mutaqoddim levels. According to the perspective of the female student at the Mutaqoddim level, when they were in the class of the opposite gender, they could exchange ideas, opinions and experience about learning Arabic to their friend in opposite gender, it made them broad-minded. They were more creative in learning so they were not bored.

However, there were some students who felt that they had not had a strong mentality when they were learning with the opposite gender, they could not express themselves and shy to ask questions or answer questions from the lecturer. This is the aspect that made the student less focused in class. But that only happened to a few students.

According to the Mutawassith female student perspective, their opinions were not much different from the opinions of female students at the Mutaqoddim level, it was heterogeneous classroom learning (female and male were mixed). They were more enthusiastic in learning and did not feel bored because in one class they did not only 
interact with female students, there was a positive impact that students did not sleep in class, because they would be embarrassed. It also created awkwardness among the opposite gender students. Because th ere were still many female students felt embarrassed, they also felt uncomfortable when they were in the mixed classes.

While the perspective of the mubtadi level female students, most of them felt embarrassed when they wanted to ask questions, express opinions when learning. That was due to the male students in the class. So that most of the students in the Mubtadi class were less active in learning, moreover they were students who had lower levels of ability under the other two levels who should need a lot of learning development in order to be able to achieve learning goals well.

However, some of the other students who felt that learning in a mixed class would have the opposite opinion, that is, they could train them to interact socially in the community which certainly consisted of men and women. There were also many things that sometimes occured, because learning was done with the opposite gender in one class, it did not rule out the possibility of many students and students who had excessive interaction with the opposite gender, such as dating. And things like this were used to found in the Mutawassith to the Mubtadi class.

From the results of the research that described, it can be seen there was a system change in grouping students from homogeneous systems which applied in the academic year of 2017/2018 to heterogeneous systems applied in the academic year of 2018/2019. Both systems have their advantages and disadvantages. There are different perspectives from each female student and male student, because it was influenced by different abilities and gender.

In Arabic Language Development Program (PKPBA) in State Islamic University of Maulana Malik Ibrahim Malang, the results of research which obtained in the homogeneous class that applied in the 2017/2018 academic year shows that the perspective of students in the 2017/2018 school year, whether mubtadi, mutawassith and mutaqoddim are mostly the same, they felt bored when they were homogeneous, which there were male students only, they felt lack of enthusiasm and cannot interact with the opposite sex in developing the ability to learn Arabic in PKPBA, so academic competitiveness was not seen and the class was noise than in the female students class.

This is different from Yulianto's finding that male students were more happy and comfortable because they like to joke around and make a good solidarity each other in 
the class. (Yulianto \& Dwijananti, 2013, p.27) This difference arises based on differences in education levels. Yulianto's research was conducted at the high school level, while for the university level, female amd male students were more interested in learning together. In relation to the lack of competitiveness by the students, this is consistent with the results of Khodijah's research in Yulianto that female gender is more diligent than men (Yulianto \& Dwijananti, 2013, p.27). The presence of women in class could trigger a competitive climate academic. Even some students felt not confident with the opposite gender students, they felt comfortable when in a homogeneous class.

According to the perspective of female students in the 2017/2018 academic year, whether the mubtadi, mutawassith or mutaqoddim level, they were more comfortable when studying in a homogeneous class. They were more focused on learning if there was no opposite gender students. This is consistent with the results of Yulianto's research that in the female students class, they interact well because of their communication skills with their classmates and they become close friend in the class (Yulianto \& Dwijananti, 2013, p.27). Just as the other previous research, (Megasari et al., 2014, p. 5) students were more focused and enthusiastic in paying attention to the teacher, it could be seen from students who respond by asking questions to the teacher.

Students felt more confident when they were learning in homogeneous class and felt free to express, so they could improve their ability to learn. They felt engrossed and enjoy without any pressure or embarrasment. Similar with the results of other research (Inne Marta Fauziyah, 1997) which states that female students were free to express and behave in all activities and they were able to show strong feminism. And according to (Muhammad Rasyid Al-waUwaid, 2005, p.282), the learning environment in a female students class can be avoided from psychological stress, ambition, and social interaction with men who always want to control.

Female students class could develop and improve their ability in the learning process.

It is different from the perspective of female students and male students in the 2018/2019 academic year from various levels, whether the mubtadi ', mutawassith or mutaqoddim levels. Both female students and male students agreed when they were learning in heterogeneous classes. One of the advantages is that they could learn to interact with the opposite gender to train their, it is needed when they are in public and also easily adapt to each other. There was academic competitiveness in the classroom. 
This is consistent with the results of Yulianto, Reni and Parker's research. In the mixed class there was a positive influence from the opposite gender, it would bring better results. Likewise, according to Rennie and Parker in mixed-class research, women were controlling male learners from aspects of behavior (Rennie, L, J \& Parker, 1997, p.257), with the presence of female students, male students would be more obedient with the rules in the class.

However, Yulianto's research also found that the conditions in mixed classes of female students and male students, the existence of opposite gender students in mixed classes caused many negative impacts on female students and male students in the form of emotions and behavior. There was awkwardness among male and female students, they felt embarrassed to communicate with each other. But some students were excited because of the opposite gender students in one class (Yulianto \& Dwijananti, 2013, p.27).

In the percentage of the results of this study, it was found from female students' perspective (30 female student informants) whether mubtadi, mutawassith, and mutaqoddim in academic year of 2017/2018 and 2018/2019 towards homogeneous classes obtained $73.33 \%$ agree, $13.33 \%$ abstain (between agree and not), and $13.33 \%$ disagree. But their perspective on heterogeneous class results obtained percentage $56.67 \%$ agree, $6.67 \%$ abstained and $36.67 \%$ disagree.

From male students' perspective (30 male student informants) whether mubtadi, mutawassith, and mutaqoddim in academic year of 2017/2018 and 2018/2019 towards homogeneous classes obtained results of $30 \%$ agree, $10 \%$ abstain, and $60 \%$ disagree. But their perspectives on heterogeneous classes obtained a percentage of $80 \%$ agree, $6.67 \%$ abstaint, and $13.33 \%$ disagree.

\section{Conclusion}

Each system has advantages and disadvantages that really impact the learning process. There are differences in student perspectives on classifications based on gender. For female students, the most of them agree with the implementation of a grouping system of students homogeneously. Students felt more comfortable when studying in a homogeneous class, felt free to express something, did not felt awkward or embarrassed even with basic Arabic language skills. This has a positive impact on students' confidence in learning and Arabic language proficiency practices. 
Wheras, the most of male students agreed with the implementation of grouping system heterogeneously. Students were more comfortable in heterogeneous classes because it made students are challenged to compete academically or socially or interacted with the opposite gender students. Students were being more obedient, and diligent, so academic competitiveness was increased. Learning process was being more vibrant and effective. No one was sleeping and doing and all the students obeyed the rules. Because of awkwardness and feeling embarrassed with the opposite gender students when they were doing something embarrassing in the class such as sleeping and others. In learning activities and arabic skill practices, the students were challenged to perform well in front of other students. Thereby, their language skills would be improved and well-practiced.

\section{References}

Abd. Rachman Assegaf. (2013). Aliran-Aliran Pendidikan Islam. Jakarta: PT Raja Grafindo Persada.

Arifin, Z. (2016). Evaluasi Pembelajaran. Bandung: PT Remaja Rosdakarya.

Glimore, D. (2002). Single Sex Classes in a Queslnd Primary School: Anevalution of

Outcomes. The Australian Educatinal and Development Psychologist 19.

Imam Ahmadi. (2015). Implementasi Pemisahan Kelas Peserta Didik Laki-laki dan

Perempuan dan Implikasinya Terhadap Motivasi Belajar Peserta Didik Kelas IX

SMP IT Masjid Syuhada Yogyakarta.

Inne Marta Fauziyah. (1997.). Inne Marta Fauziyah, Peran Jenis Kelamin Dan Tingkat Aspirasi Akademis pada Siswi SMU co-educasi dan non co-edukasi. 9.

Iqbal, A. F. (2018). Efektivitas Kelas Belajar Homogen dalam Pembentukan Karakter Peserta Didik di SMP Bilingual Terpadu Krian.

Megasari dkk. (2014). Pola Interaksi Berbasis Gender dalam Pembelajaran Sosiologi

Siswa Kelas X “ 3,. Jurnal Pendidikan Dan Pembelajaran.

Muhammad Rasyid Al-'Uwaid. (2005). Risalah Mukminah:Jangan Terpedaya

diterjemahkan oleh Bahrun Abu Bakar Ihsan Zubaidi. Bandung: Rsyad Baitus

Salam I.

Program Khusus Pengembangan Bahasa Arab. (2017). Buku Panduan Program Khusus

Pengembangan Bahasa Arab (PKPBA).

Rayhan Putri. (2016). Manifestasi Kesetaraan Gender Di Perguruan Tinggi Fakultas

Tarbiyah dan Keguruan Universitas Islam Negeri Ar-Raniry Banda Aceh, 2(July), 
$164-182$.

Rennie, L,J \& Parker, L (1997). Student's and Teacher's Perception of Single Sex and Mixed-Sex Mathematics Classes. Mathematics Education Research Journal.

Saraswati, E. (2015). Perbedaan Hasil Belajar Siswa Laki-Laki dan Perempuan dalam Mata Pelajaran Matematika Kelas III Semester 2 Materi Sudut Dan Pecahan Di SD Negeri se-Desa Caturharjo, Kecamatan Sleman, Kabupaten Sleman.

Taqiyah, B. (2016). Pengaruh Pemisahan Kelas Peserta Didik Laki-Laki dan Perempuan terhadap Motivasi Siswa Kelas X MA Sunan Pandanaran Yogyakarta.

Warni Tune Sumar. (2004). Implementasi Kesetaraan Gender Dalam Bidang Pendidikan, Yulianto, T., \& Dwijananti, P. (2013). Studi Perbandingan Hasil Belajar Fisika Sesaat Kelas Putra, Kelas Putri, dan Kelas Campuran pada Materi Getaran di SMA N 1 Kradenan Kabupaten Grobongan. Unnes Physics Education Journal, 2(2).

Zakia, M. G. (2011). Sistem pengelompokan peserta didik di sekolah dasar negeri, (3). 